Інна ВЛАСЕНКО, orcid.org/0000-0001-7335-8300 кандидат філологічних наук, стариий викладач кафедри англійської філології Чорноморського національного університету імені Петра Могили (Миколаїв, Україна) ascuteasacupcake8@gmail.com

\title{
КЛЮЧОВІ АСПЕКТИ АНАЛІЗУ АВТОРСЬКОЇ ЛЕКСИКИ У ЖАНРІ ФЕНТЕЗІ
}

Кожен літературний твір, створений автором, відбиває його внутрішній світ, ідіолект, світовідчуття, мовну свідомість. Письменник є дослідником, який пізнає навколишній світ, а результати иього пізнання відбиваються в тексті його твору за допомогою мови. Мовні особливості художнього тексту уведені до тексту з метою відбиття реалій вторинного світу, створеного в уяві автора. Твори такого типу належать до літературного жанру фентезі, щ⿻о характеризується наявністю великої кількості нових слів - «авторських новотворів» або «оказіоналізмів», які виникають під впливом контексту на основі типової (узуальної) або нетипової (оказіональної) моделі.

Стаття викладає методичні аспекти аналізу оказіональних одиниць жанру фентезі, що функиіонують у творах британських, німецьких та украӥнських письменників. Процес комплексної інтерпретації оказіональних лексичних одиниць багаторівневий і містить такі складові частини, як аналіз способу творення лексеми, компонентний і контекстуальний аналізи, а також дослідження засобів і проблем їхнього перекладу.

Структура оказіоналізмів досить часто не відповідає нормі, саме тому моделі словотвору, використовувані в корпусі оказіональних лексем жанру фентезі, не можуть бути обмежені узуальними засобами. Цей факт спричинює появу значної кількості оказіональних способів, серед яких найпродуктивнішими для жанру фентезі є онімізація, альтернація, редеривація, десегментачія, анаграма, семантичний спосіб, засіб оказіонального поєднання слів тощуо. Під час інтерпретащії авторських одиниць значну роль відіграє дослідження контексту, в якому вони функціонують, оскільки досить часто саме так звані «контекстуальні актуалізатори» (лексичні, затекстові) розкривають значення тієї чи іншої лексеми. Дослідження контексту й структури оказіональних новотворів дає змогу виділити шляхом компонентного аналізу інтегральні й диференційні семи в корпусі аналізованих оказіоналізмів. Цей процес є досить важливою ланкою інтерпретаційного апарату, оскільки, окрім аналізу семантичних характеристик, він дає можливість розподілити оказіональні лексеми за групами й підгрупами згідно з їхньою семантикою. Крім того, інтерпретачія іншомовних авторських новотворів неможлива без аналізу їхнього перекладу українською мовою. Цей етап необхідний, оскільки український перекладач часто неправильно інтерпретує та передає украӥнською мовою одиниці такого типу, та, як наслідок, читач стикається 3 проблемою нерозуміння значення оказіональних новотворів, щчо спричинює хибне сприйняття тексту в цілому.

Ключові слова: оказіоналізм, фентезі, узуальні / неузуальні засоби словотвору, контекстуальні актуалізатори, компонентний аналіз.

Inna VLASENKO, orcid.org/0000-0001-7335-8300 Candidate of Philological Sciences, Senior Lecturer at the Department of English Philology Petro Mohyla Black Sea National University (Mykolaiv, Ukraine) ascuteasacupcake8@gmail.com

\section{KEY ASPECTS OF THE ANALYSIS OF AUTHOR'S VOCABULARY IN THE FANTASY GENRE}

Each work of literature created by an author reflects its inner world, idiolect, linguistic consciousness. The author is a kind of researcher who discovers the world and the results of this cognition are described in his work. Language means of a fiction text are included into it with the object of depicting the realities of the secondary world created in the author's imagination. The works of such type belong to the fantasy genre which is characterized by the numerous amount of new lexemes - "author's neologisms" or "nonce-words" which appear under the influence of the context on the basis of typical (usual) or untypical (occasional) pattern of word-formation.

This article covers the key points of methodological aspect of the nonce-words analysis in the fantasy genre which function in the novels created by the English, German and Ukrainian writers. The process of the complex interpretation of nonce-words is multilayer and includes such constituents as derivational analysis, componential and contextual analyses as well as the studying of translation means and main issues connected with this topic. 
The structure of nonce-words is seldom coincide with the norms that's why the derivational patterns applied to the corps of fantasy nonce-words cannot be restricted by usual ways of word-formation. This fact causes the appearance of the large amount of occasional means of word-formation. The most productive are considered to be the following: onimization, alternation, rederivation, desegmentation, anagram, semanatic method, occasional word-combination etc. In the process of interpretation of the authors'vocabulary one of the main issues is devoted to the contextual analysis as frequently so called "textual actualysts" (lexical and non-text) reveal the core the meaning of a particular lexeme. The study of contextual and structural aspects of each nonce-word makes it possible to deduce with the help of componential analysis the differential and integral semes in the corps of the nonce-words under analysis. This process is considered to be extremely essential stage of interpretational apparatus as, besides revealing the semantic characteristics of given lexemes, it enables the distinguishing of the nonce-words into semantic groups and subgroups according their semantic peculiarities. It also should be mentioned that the interpretation of the foreign authors'lexemes is impossible without the analysis of the issues which concern their translation into Ukrainian. This stage is essential as Ukrainian translators frequently interpret these lexemes in a wrong way and as a result Ukrainian reader face the problem of misinterpretation of such words which causes the incorrect perception of the fantasy text in general.

Key words: nonce-word, usual / occasional means of word-formation, contextual actualysts, componential analysis.

Постановка проблеми. Авторська оказіональна лексика, яка $є$ художнім та естетичним надбанням, вважається важливим стилістичним засобом, що характеризується унікальним смисловим навантаженням. Оказіональне слово є однією 3 ключових ознак певних літературних жанрів, таких як жанр фентезі. Цей жанр дає можливість авторові на сторінках літературного твору створити уявний світ з оригінальною системою персонажів, подій, місць їх перебігу. Особливість жанру полягає в тому, що він сам спонукає письменника до створення засобів, які слугують для урізноманітнення художнього простору творів - вигаданих мов, алфавітів, власних глосаріїв, імен вигаданих персонажів тощо. Кожен оказіоналізм є складовою частиною створеної автором культури вторинного світу, етносу, відбиває його традиції та звичаї.

Аналіз досліджень. У науковій літературі зустрічається велика кількість назв і класифікацій оказіональної лексики. Існування значної кількості термінів для позначення цього явища є наслідком розходження спеціалістів у його розумінні, хоча більшість дослідників дотримуються назви оказіоналізми. Термінологічні розбіжності $\epsilon$ не єдиним спірним питанням під час вивчення оказіональних слів. Стрімкий розвиток неологіїнауки, що вивчає нові слова, - спричинив появу різних підходів до класифікації та критеріїв розмежування нових слів. Так, дослідники оказіональної лексики пропонують виділяти оказіоналізми трьох ступенів у залежності від ступеня їх нормативності, семантичні, лексичні, графічні, граматичні оказіоналізми на основі їх структурних особливостей, групи оказіоналізмів за способом їх творення тощо (Ханпіра, 1966; Ликов, 1971; Лопатін, 1969, Мартиненко, 2002).

Мета статті. Дослідження теоретичних джерел, присвячених жанру фентезі й оказіоналізмам як однієї 3 його особливостей, проблем, пов'язаних 3 їх тлумаченням i класифікацією, уможливило розробку принципів аналізу оказіональних авторських новотворів, що функціонують у жанрі фентезі.

Виклад основного матеріалу. Комплексний підхід до вивчення індивідуально-авторських новотворів жанру фентезі базується на сучасних лінгвістичних теоріях і методах, що містять різноманітні методики аналізу, не підпорядковані одній меті. Насамперед в основу аналізу покладено інтегративний підхід до кожної авторської інновації в тексті. Процес комплексної інтерпретації оказіональних лексичних одиниць багаторівневий і містить такі складові частини, як аналіз способу творення лексеми, компонентний і контекстуальний аналізи, а також дослідження засобів і проблем їх перекладу.

Інтерпретація будь-якого індивідуально-авторського новотвору залежить від його приналежності до певного класу. Цей розподіл грунтується переважно на характері дослідження в цілому. Проте слід враховувати той факт, що оказіональні одиниці є нестандартними утвореннями, що функціонують, головним чином, поза узусом, тому процес класифікації того чи іншого оказіонального корпусу лексем є досить складним і суперечливим явищем. На нашу думку, найбільш обгрунтованою класифікацією, на основі якої видається можливим зробити поділ оказіональної лексики жанру фентезі, є класифікація А. В. Суперанської. Дослідниця вважає доцільним розподіляти лексичні одиниці, присутні в будь-якій мові, на «оніми» (власні назви) й «апелятиви» (всі лексеми, які не є онімами) (Суперанская, 1973: 134).

Отже, аналіз оказіональної лексики, створеної письменниками-фантастами, необхідно здійснювати в декілька етапів, першим 3 яких $є$ дослідження структури авторських лексем, що дає можливість на наступних етапах проаналізувати ï семантику, особливості функціонування одиниць у контексті, а також переклад. Структура 
оказіоналізмів різниться від узуальної до суто оказіональної, тому проаналізувати їхню структуру, спираючись лише на наявні в мові словотворчі моделі, досить складно. Сучасні дослідники оказіональної лексики, такі як О. А. Пуліна, Р. Ю. Намітокова, І. С. Улуханов, В. М. Бєрєнкова тощо висувають теорію, згідно 3 якою в мові поруч з узуальними моделями (словоскладання, суфіксальний і префіксальний засоби, конверсія) існує певний набір оказіональних, тобто ненормативних засобів словотворення, використовуваних саме для творення оказіональних одиниць. Серед них найпродуктивнішими стосовно оказіонального корпусу лексем жанру фентезі є такі:

1. «Контамінація» - оказіональний засіб словотворення, що є різновидом нормативного способу словоскладання. Зазначений засіб втілюється шляхом сполучення двох узуальних слів, останне 3 яких використовується переважно в усіченому вигляді. (“Biennenstich”- укр. Осакус).

2. Ще один тип словоскладання, що зустрічається в оказіональному словотворенні - «міжслівне накладання слів». Під час використання такого прийому слова нашаровуються одне на одне таким чином, що кінець першого компоненту складної лексичної одиниці стає початком другого (“Rictusempra" - укр. Ріктусемпра).

3. «Альтернація» - графічна й фонетична видозміна основи слова без зміни його змістової складової частини. Зазначений засіб переважно втілюється шляхом заміни в основі лексеми декількох фонем (“Hogwarts” - укр. Гогвортс, "Uylala"- укр. Уюляля).

4. Метатезний словотвір - один із варіацій альтернації, що полягає в обопільній перестановці звуків у словах, що контактують. Такий процес відбувається переважно в оказіональних словосполученнях. (“Durmstrang”- - ккр. Дурмстренг).

5. Тмезис - спосіб, втілений в авторському оказіональному словотворенні шляхом додавання до основи узуальної лексичної одиниці певних морфем, що переважно не спричинює змін семантичного характеру, а породжує лише фонетичні й іноді граматичні трансформації в структурі слова (“Azkaban"-укр. Азкабан, "Ваигео”-укр. Баурео).

6. «Редеривація» - зворотний спосіб словотвору, що полягає в усіченні певної частини узуальної лексеми (“Diagon (Alley)" - укр. Алея Діагон).

7. «Десегментація» - підтип редеривації, використовуваний у разі усічення фінального компонента узуальної лексеми ("Knockturn (Alley)" укр. Алея Ноктерн, "Urgl" - укр. Уртль).

8. Анаграма - оказіональний спосіб, що полягає в трансформації узуального слова шляхом зміни порядку морфем із метою отримання іншої лексеми. Такий засіб переважно використовується для творення оказіональних антропонімічних одиниць (“Lord Voldemort" - укр. Лорд Волдеморт).

9. Засіб оказіонального посднання слів засіб словотвору, що має на меті поєднання так званих «несумісних» понять, тобто порушення звичних моделей, зумовлених нормою та логікою. Використання зазначеного способу спричинило появу одного 3 типів індивідуально-авторських лексем - «незвичайні» поєднання слів - оказіональних словосполучень. Семантика компонентів такого типу знаходиться в стані семантичного конфлікту, тобто суперечить узуальним нормам (“die Sümpfe der Traurigkeit” - укр. Болота Смутку, "Shrieking Shack" - укр. Вересклива Халупа).

10. Семантичний засіб - оказіональна модель, що передбачає формування нових семантичних прирощень в узуальній лексемі. Такий спосіб зумовлює появу досить розповсюдженого типу оказіональних одиниць - семантичних оказіоналізмів - нормативних лексем, наділених автором у контексті новим значенням, незазначеним у словниках ("Cockatrice" - укр. Василіск, “Аигуn” - укр. Аурин).

Окрім аналізу структурної складової частини, для визначення семантичних характеристик певної авторської лексеми, що надалі даватиме змогу виділити в корпусі оказіональних одиниць семантичні домінанти й розподілити їх за тематичними групами, важливу роль відіграє контекст, в якому той чи інший оказіоналізм функціонує. Традиційно лексеми розподіляють «у залежності від їх функцій у мовленні на одиниці семантичного й одиниці метасемантичного рівня: під семантичною функцією розуміється передача поняттєвої інформації, а під метасемантичною - емоційний вплив на реципієнта» (Соскіна, 1980: 12). Для оказіоналізмів художнього тексту характерною $є$ метасемантична функція, оскільки головною їх метою $є$ образність, «виклик емоційного сплеску в читача» на певному етапі оповіді (Соскіна, 1980: 12). Авторські новотвори, що функціонують у тексті, $€$ так званою «інформаційною моделлю», зафіксованою комплексною інформацією, яку «адресат тексту <...> отримує та обробляє та яка складає частину загального інформаційного поля тексту» (Васильєва, 2005: 10-11). Безумовно, оказіональні одиниці більш ніж будь-які інші лексеми прив'язані до тексту. Саме тому авторські новотвори слід розглядати у двох напрямах: аналіз одиниці в тексті в межах «мікротекстології» - найближчий контекст слова, а також «макротекстології», коли «простором реалізації властивостей і функцій авторських новотворів стає цілий текст» (Соскіна, 1980: 13). 
На думку багатьох дослідників (О. А. Земської, А. Г. Ликова, Р. Ю. Намітокової, С. Н. Соскіної тощо), контекст, в якому функціонує оказіональне слово, має особливу структуру, що полегшує його сприйняття. У цьому процесі значну роль відіграють «семантичні визначення» (Н. В. Новікова), «ідентифікатори» (Н. В. Васильєва), «стимули» (О. А. Габинська), «актуалізатори» (Р. Ю. Намітокова), які так чи інакше дають пояснення оказіональній одиниці.

Серед так званих «актуалізаторів» авторських лексем слід зазначити «лексичний (текстовий)» $\mathrm{i}$ «затекстовий». Досить поширеним явищем у фентезійному жанрі літератури $\epsilon$ «текстові актуалізатори», використовувані для семантизації оказіоналізмів. У процесі текстової актуалізації «контекст інтерпретує новотвір безпосередньо, тобто спеціальними ремарками - графічно або поясненням вказує на оказіоналізм; або посередньо, тобто семантизує оказіоналізм змістом мікро / макроконтексту» (Намітокова, 1989: 230). Значну роль у творах фентезі відіграють також «затекстові актуалізатори», які передбачають знання реципієнтом мови оригіналу, історії та культури вторинного світу, створеного автором.

Дослідження контексту й структури авторських новотворів даватиме можливість переходу до наступного етапу їх інтерпретації, а саме виокремлення спільних сем у значенні корпусу оказіоналізмів жанру фентезі, що грунтується на принципах методу компонентного аналізу. Зазначений метод передбачає «вивчення семантики мовних одиниць», що має на меті «розкласти значення мовної одиниці» на мінімальні елементи або семи. Їхнє виокремлення в значенні слова проводиться шляхом зіставлення 3 іншими лексичними одиницями, які мають із нею семантичну єдність. Виділення семантичних компонентів проводиться на підставі дослідження словникових дефініцій компонентів оказіонального новотвору. Структурну організацію компонентів оказіоналізму, які не містять словникових тлумачень, визначають на підставі дослідження його контекстуальних властивостей. Аналіз семантики оказіональних лексем дає змогу утворити так звані семантичні поля або семантичні групи шляхом розподілу одиниць відповідно до виявлених інтегральних сем. Окрім виявлення спільних семантичних компонентів оказіональних одиниць із метою виділення інтегральних сем або архісем, проводимо зіставлення дефініцій оказіональних одиниць у межах кожної семантичної групи, що спричинює виокремлення диференційних сем та, як наслідок, появу семантичних підгруп, які дають змогу конкретизувати значення та функції в тексті певного комплексу оказіоналізмів.

Наступним етапом інтерпретації оказіональних новотворів жанру фентезі є аналіз способів їх перекладу українською мовою, що є досить важливою проблемою для українських читачів, оскільки значна кількість видатних творів фентезі написана зарубіжними авторами-фантастами. У порівнянні $з$ минулими десятиріччями, коли більшість читацької аудиторії надавала перевагу російській версії зарубіжних творів, в останні роки популярність українських перекладів значно зросла, тому дослідження перекладу популярних фентезійних творів $є$ нагальною потребою. Однією з проблем, пов'язаних із перекладом творів фентезі, $є$ саме передача оказіональних одиниць, які, як відомо, переважно не мають аналогів у мові-реципієнті. Питання про переклад оказіоналізмів протягом багатьох років розроблялося такими дослідниками, як В. С. Виноградов, В. Н. Комісаров, А. Г. Ликов, А. Д. Швейцар тощо, тому вже розроблено апарат принципів перекладу оказіоналізмів, на основі якого проводитиметься дослідження оказіоналізмів у фентезійному жанрі літератури. Згідно 3 теоріями, пов'язаними 3 перекладом узуальних лексем, дослідниками запропоновано універсальні способи перекладу оказіоналізмів:

1. «Метод транслітерації» полягає в тому, щоб за допомогою українських морфем передати складові частини англійського слова. Транслітерація широко використовувалася перекладачами до кінця XIX століття. Для цього необов'язково було знати вимову певного оказіонального слова, а лише обмежитися його зоровим сприйняттям.

2. Провідним способом в сучасній перекладацькій практиці $\epsilon$ «транскрипція» зі збереженням деяких елементів транслітерації. Для кожної пари мов розробляються правила передачі звукового складу слова початкової мови, вказують випадки збереження елементів транслітерації та традиційні винятки 3 правил, загальноприйнятих натепер. У перекладах вони найчастіше зустрічаються під час транскрибування елементів деяких невимовних приголосних і зредукованих голосних.

3. Серед власне перекладних способів в окрему ланку виділяється «калькування» - це спосіб перекладу лексичної одиниці оригіналу шляхом заміни ії складових частин - морфем або слів їх лексичними відповідниками в мові-реципієнті. Калькування припускає існування двосторонніх міжмовних відповідників між елементарними лексичними одиницями, які й використовуються як «будівельний матеріал» для відтворення внутрішньої форми запозиченого або перекладеного слова. 
4. «Описовий переклад» - це лексико-граматична трансформація, під час якої лексична одиниця початкової мови замінюється словосполученням, що експлікує її значення, тобто дає досить повне пояснення або визначення оригінального оказіоналізму. Описовий переклад полягає в передачі значення іншомовного слова за допомогою більш-менш поширеного пояснення.

5. «Функціональна заміна» є особливо актуальним способом у разі так званої «безеквівалентної» лексики, тобто коли жоден із відповідників, запропонованих словником, не підходить для конкретного контексту. Цей засіб перекладу по суті $€$ процесом створення нового слова в мові-реципієнті, яке б відбивало семантику оригінального оказіоналізму.

Висновки. Таким чином, дослідження теоретичних джерел, присвячених жанру фентезі й оказіоналізмам як однієї з його особливостей, проблем, пов'язаних з їх тлумаченням і класифікацією, уможливило розробку принципів аналізу оказіональних авторських новотворів, що функціонують в жанрі фентезі. Інтерпретація так званих «фентезійних» оказіональних одиниць має бути комплексним процесом, який містить семантичну складову частину, що полягає у виявленні інтегральних і диференційних сем у внутрішній формі компонентів оказіональних одиниць, виокремлених у ході дослідження їхньої структури, що переважно не відповідає нормативним моделям словотвору. Крім того, зазначимо функціональну складову частину, що застосована з метою інтерпретації контекстуальних властивостей авторських одиниць, а також аналіз технік перекладу новотворів українською мовою.

\section{СПИСОК ВИКОРИСТАНИХ ДЖЕРЕЛ}

1. Беренкова В. М. Авторские новообразования и их функции в трилогии Дж. Р. Р. Толкиена «Властелин колец» (в английском и русском языках) : дис. ... канд. филол. наук : 10.02.01, 10.02.20 ; Науч. б-ка Адыгейского государственного университета. Майкоп, 2003. 189 с.

2. Васильева Н. В. Собственное имя в мире текста : монография. Москва, 2005. 224 с.

3. Лопатин В. В., Улуханов И. С. К соотношению единиц словообразования и морфологии. Единищы разных уровней грамматического строя языка и их взаимодействие : сборник научных трудов. Москва, 1969. Вып. 12. С. 119-132.

4. Лыков А. Г. Окказиональное слово как лексическая единица речи. Филологические науки. Москва, 1971. № 5. C. 70-81.

5. Мартовод К. Ю. Семантична інтерпретація оказіоналізму. Держава та регіони. Серія : «Гуманітарні науки». Запоріжжя, 2009. № 3-4. С. 36-41.

6. Мартиненко Ю. Б. Антропонимы-неологизмы в творчестве Велимира Хлебникова. Диалог 2002. Компьютерная лингвистика и интеллектуальные технологии : материалы международной конференции, г. Бекасово, 27-31 мая 2009 г. Москва, 2002. С. 47-51.

7. Намитокова Р. Ю. Авторские новообразования : структура и функционирование : дис. ... д-ра филол. наук : 10.02.04 ; Научная б-ка Адыгейского государственного университета. Майкоп, 1989. 187 с.

8. Пулина Е. А. Окказиональное слово в художественном тексте: способы образования и межъязыковой трансляции (на материале романа Дж. Джойса «Улисс» и его переводов на русский и немецкий языки) : автореф. дисс. ... канд. филол. наук : 10.02.19. Пермь, 2008. 22 с.

9. Соскина С. И. Окказиональные образования научной фантастики (на материале английского языка) : автореф. дисс. ... канд. филол. наук : 10.02.04. Ленинград, 1980. 22 с.

10. Суперанская А. В. Общая теория имени собственного : учебное пособие. Москва, 1973. 366 с.

11. Ханпира Э. И. Об окказиональном слове и окказиональном словообразовании. Развитие словообразования современного русского языка : сборник научных трудов. Москва, 1966. С. 153-166.

\section{REFERENCES}

1. Berenkova V. M. Avtorskie novoobrazovaniya i ikh funkczii v trilogii Dzh. R. R. Tolkiena „Vlastelin kolecz” (v anglijskom i russkom yazy 'kakh): dis. ... kand. filol. nauk : 10.02.01, 10.02.20 [Autor's neologisms and their functions in trilogy by J.R.R. Tolkien "The Lord of Rings" : thesis ... for the Candidate of Philol. Sciences]/ The Scientific Library of Adygey state university. Majkop, 2003 [in Russian].

2. Vasileva N. V. Sobstvennoe imya v mire teksta : monografiya [Proper names in the world of text : monograph]. Moskva, 2005. $224 \mathrm{p}$ [in Russian].

3. Khanpira E. I. Ob okkazional'nom slove i okkazional'nom slovoobrazovanii [About nonce-word and occasional word-formation]. The development of Russian word-formation : collection of scientific works. Moskva, 1966. pp. 153-166 [in Russian].

4. Lopatin V. V., Ulukhanov I. S. K sootnosheniyu edinicz slovoobrazovaniya i morfologii [Concerning the correlation of the units of word-formation and morphology]. The Units of different language levels and their interaction : collection of scientific works. Moskva, 1969. Nr. 12. pp. 119-132 [in Russian].

5. Lykov A. G. Okkazional'noe slovo kak leksicheskaya edinicza rechi [Nonce-word as a lexical unit of speech]. Philological studies. Moskva, 1971. № 5. pp. 70-81 [in Russian].

6. Martovod K. Yu. Semantychna interpretatsiia okazionalizmu [Semantic interpretation of a nonce-word]. The state and its regions. Series : The humanities. Zaporizhzhia, 2009. № 3-4. S. 36-41[in Ukrainian]. 
7. Martinenko Yu. B. Antroponimy-neologizmy v tvorchestve Velimira Khlebnikova [Antroponymic neologizms in Velimir Khlebniov's works]. Dialogue 2002. Computer linguistics and intellectual technologies : materials of international conference. (Bekasovo, May, 27-31, 2009). Moskva, 2009. pp. 47-51 [in Russian].

8. Namitokova R. Yu. Avtorskie novoobrazovaniya : struktura i funkczionirovanie : dis. ... d-ra filol. nauk : 10.02 .04 [Autor's neologizms: structure and functioning : thesis ... for Doctor of Philological Sciences : 10.02.04] / Scientific library of Adygey state university. Majkop, 1989 [in Russian].

9. Pulina E. A. Okkazional'noe slovo v khudozhestvennom tekste: sposoby` obrazovaniya i mezhyazykovoj translyaczii (na materiale romana Dzh. Dzhojsa „Uliss” i ego perevodov na russkij i nemeczkij yazy ki) : avtoref. diss. na soiskanie nauch. step. kand. filol. nauk [Nonce-words in a literary text : ways of word-formation and interlingual compilation (on the basis of the novel by J. Joyce "Ulysses" and its translations into Russian and German) : abstract of the thesis for the science degree of Candidate of Philological Sciences]. Perm’, 2008. 22 p [in Russian].

10. Soskina S. I. Okkazional ’nye obrazovaniya nauchnoj fantastiki (na materiale anglijskogo yazy`ka) : avtoref. diss. na soiskanie nauch. step. kand. filol. Nauk [Nonce-words in science fiction (on the basis of the English language) : abstract of the thesis for the science degree of Candidate of Philological Sciences]. — Leningrad, 1980. $22 \mathrm{p}$ [in Russian].

11. Superanskaya A. V. Obshhaya teoriya imeni sobstvennogo : uchebnoe posobie [The general theory of proper names : handbook]. Moskva, 1973. 366 p [in Russian]. 